\title{
Arrested Pneumatization of the Skull Base and its Relationship with Sphenoid Sinus Hypoplasia; A Cross-Sectional Retrospective Study.
}

Kafa Tabanı Arrested Pnömatizasyonu ve Sfenoid Sinüs Hipoplazisi ile İlişkisi Kesitsel Retrospektif Çalısma

${ }^{1}$ Basak Atalay, ${ }^{2}$ Umut Percem Orhan Soylemez

${ }^{1}$ Istanbul Medeniyet University, School of Medicine. Goztepe Prof.Dr.Suleyman Yalcin City Hospital Department of Radiology, Istanbul, Turkey

${ }^{2}$ Goztepe Prof.Dr.Suleyman Yalcin City Hospital Department of Radiology, Istanbul, Turkey
Correspondence:

Bașak ATALAY

Istanbul Medeniyet University,

School of Medicine. Goztepe

Prof.Dr.Suleyman Yalcin

City Hospital Department of

Radiology, Istanbul, Turkey

e-mail: basak_hosgoren@yahoo.com

\section{Abstract}

Arrested pneumatization is a developmental condition that can be an incidental finding on CT and MR imaging and may be confused with aggressive skull base diseases. This study aimed to detect the prevalence of arrested pneumatization of the skull base and to find out the relationship with sphenoid sinus aeration. Paranasal sinus CTs performed between January 2020 to June 2020 were evaluated in a retrospective manner. 841 CT exams were included in the study. The included CT examinations were evaluated independently by two observers for the presence of arrested pneumatization in the skull base. The sides, localization, and dimensions of the arrested pneumatization in the skull base were noted. Localization was grouped as basisphenoid, right and left pterygoid processes. The lesions with sclerotic margins, with the presence of fat, soft tissue densities and curvilinear internal calcifications were accepted as arrested pneumatization. The correlation between the presence of arrested pneumatization with sphenoid sinus aeration and the location and size of the lesion was evaluated. Sixty-two (7.4\%) arrested pneumatization were detected. Sphenoid sinus hypoplasia was seen in $8(0.95 \%)$ patients and was significantly more frequent in patients with arrested pneumatization $(\mathrm{p}=0.0001)$. There wasn't any significant difference for age and gender between individuals with arrested pneumatization and other individuals. Arrested pneumatization of the sphenoid sinus was seen at a rate of 7.4 percent. This is an anatomical variation that can be considered as a pseudo-lesion and may be associated with sphenoid sinus hypoplasia.

Keywords: Arrested pneumatization, Computed tomography, Skull base, Sphenoid sinus

\section{Özet}

Kafa tabanında arrested pnömatizasyon, BT ve MR incelemeler esnasında rastlantısal olarak karşılaşılabilen ve agresif kafa tabanı lezyonlar ile karıștırılabilen gelișimsel bir durumdur. Bu çalıșma kafa tabanı arrested pnömatizasyonunun prevelansını çalıșma grubunda saptamayı ve sfenoid sinus hipoplazisi ile ilișkisini değerlendirmeyi amaçlamıștır. Ocak-Haziran 2020 tarih aralığında hastanemizde çekilmiș olan paranazal sinus BT tetkikleri geriye dönük olarak tarandı. Çalışmaya 841 BT tetkiki dahil edildi. Tüm imajlar iki araştırmacı tarafından bağımsız şekilde değerlendirildi. Her iki araştırmacı; kafa tabanında arrested pnömatizasyon varlığını, sonrasında boyutu ve lokalizasyonunu değerlendirdi. Lokalizasyon; bazisphenoid yerleșimli, sağ ve sol pterygoid proses yerleșimli olarak üç gruba ayrıldı. Sklerotik kenarları olan, içerisinde yağ dansitesi, yumuşak doku dansitesi ve kalsifikasyon bulunan lezyonlar arrested pnömatizasyon olarak kabul edildi. Arrested pnömatizasyon varlığı, varlığında sfenoid sinus havalanması ile ilişkisi, lokalizasyonu değerlendirildi ve boyutu ölçüldü. 62 (\%7.4) hastada arrested pnömatizasyon, 8 (\%0.95) hastada ise sfenoid sinus hipoplazisi izlendi. Sfenoid sinus hipoplazisi arrested pnömatizasyonu olan hastalarda istatistiksel olarak anlamlı șekilde daha sıktı $(\mathrm{p}=0.0001)$. Arrested pnömatizasyon görülen ve görülmeyen gruplar arasında yas ve cinsiyet açısından anlamlı fark saptanmadı. Çalışmaya dahil ettiğimiz grupta \%7.4 oranında görülen, kafa tabanı lezyonları ile karıştırılabilen arrested pnömatizasyon nadir görülmeyen bir anatomik varyasyon olup sfenoid sinus hipoplazisi ile ilişkili olması muhtemeldir.

Anahtar Kelimeler: Arrested pnömatizasyon, Bilgisayarlı Tomografi, Kafa tabanı, Sfenoid sinüs 


\section{Introduction}

Aeration follows the fatty transformation of the bone marrow during the development of the sphenoid sinus. This is a process that begins at the first year of life and continues until the adolescent period $(1,2)$. When this development period is interrupted, fatty bone marrow can be trapped, which is named as "arrested pneumatization" (2). In some individuals, fatty marrow adjacent to the sinus persists for unknown reasons. Absent or hypoplastic sinuses, accessory pneumatization are well-known anatomical variations of the skull base. Arrested pneumatization is a less recognized condition that may confused with other osseous pathologies like fibrous dysplasia or chondrosarcoma (3). It is named as one of the pseudo- lesions (don't touch lesion) in head and neck radiology, especially since the MR image can be misleading (4).

It is ambiguous why arrested pneumatization has been occurred frequently in the sphenoid sinus, though it may be due to greater variances of pneumatization of the sphenoid sinus $(2,3)$. Besides, there is a theory claiming that; aeration triggers fatty conversion in the sphenoid sinus (5), another hypothesis suggests that the ratio of trabecular bone to cortical bone is the driving mechanism (6). Also there is an ongoing debate that the local blood flow changes lead the persistence of atypical fatty bone marrow until adulthood (7). Although the exact mechanism for arrested pneumatization is yet to be explained, some studies had found out that, its prevalence is increased in patients with some

Table 1. Paranasal sinus CT imaging parameters hematological disorders such as sickle cell anemia $(2,8)$.

This study aimed to determine the prevalence of arrested pneumatization of the skull base in a screened population and the hypothesis of this study was that arrested pneumatization of the skull base may have a relation with aeration of the sphenoid sinus.

\section{Materials and Methods}

This retrospective study was conducted after the university local ethics committee approval (approval ID: 2020/0435).

Since sphenoid sinus aeration may extend until adolescance, patients aged 16 years and over were included in the study (7). Images with inadequate image quality (without thin section, with artefacts, doesn't include all sphenoid sinus), patients under the age of 16 , with skull base fracture, with lesions such as metastasis, tumor, Paget disease, osteoradionecrosis, fibrous dysplasia involving skull base were excluded the study. Finally 841 Paranasal sinus CT images were included.

All paranasal sinus CT scans in this study were performed on a GE Optima CT660 device (GE Healthcare, Milwaukee, WI, USA) at our university hospital using an axial-plane bone window and reformatted images of the paranasal sinuses. The CT acquisition parameters are summarised in Table 1.

\begin{tabular}{|c|c|c|c|c|c|c|}
\hline mAS & $\mathbf{k V}$ & Pitch & $\begin{array}{l}\text { Slice } \\
\text { thickness }\end{array}$ & Matrix & FOV & Scan time \\
\hline 100 & 100 & 0,984 & $\begin{array}{l}1,25 \mathrm{~mm} \\
(0,625 \\
\text { reformatted) }\end{array}$ & $512 \times 512$ & $200 \mathrm{~mm}$ & $2,8 \mathrm{sec}$ \\
\hline
\end{tabular}

\section{Arrested pneumatization and sphenoid sinus evaluation}

Welker's criteria were used to detect the arrested pneumatization (3). Lesions are located in a site of pneumatization of the skull base, a region of asymptomatic abnormal density that is incidentally found on CT imaging with the following criteria; 1) well- circumscribed and sclerotic borders, 2) internal fat density zones, 3) internal soft tissue density zones, 4) curvilinear internal calcifications (Fig. 1). Expansion and the adjacent neural foramina were also evaluated for destruction or invasion. The location of 
arrested pneumatization was classified as; located at basisphenoid, right and left pterygoid process (Fig. 2). Axial and anteriorposterior diameters of the lesion were measured as well. Lesions were classified as $-1 \mathrm{~cm}$ and $\geq 1 \mathrm{~cm}$. Sphenoid sinus aeration was interpreted as normal, aplasia, or hypoplasia. In sagittal reformatted images a vertical line through the tuberculum sella was drawn; sphenoid sinus aeration located in front of this line is accepted as hypoplasia (9) (Fig. 3).
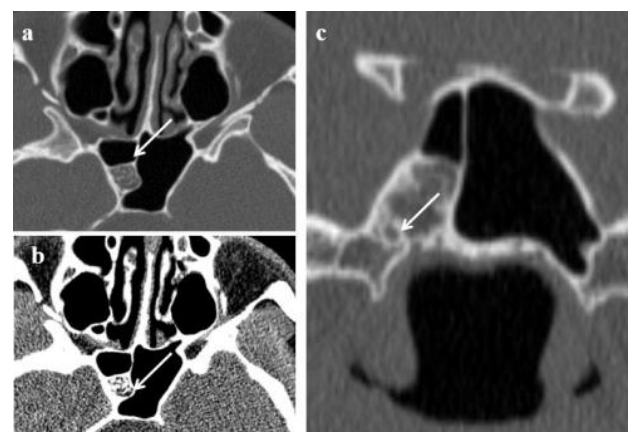

Fig. 1; The description of arrested pneumatization 1a; a lesion with curvilinear internal calcifications protruding into the right half of the sphenoid sinus (arrow) $\mathbf{1 b}$; In soft tissue window, fat densities in the lesion (arrow) 1c; the lesion does not show any destruction or invasion with the adjacent neural foramen (arrow).

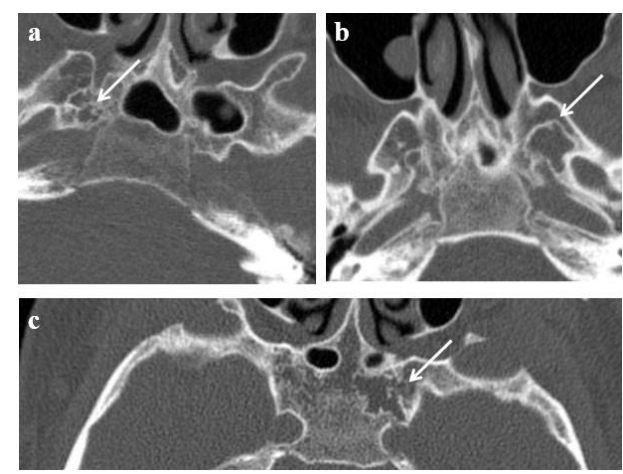

Fig.2; Definition of sphenoid sinus aeration with a drawn vertical line touching the anterior border of tuberculum sella in midsagittal CT images

$2 \boldsymbol{a}$; Normal aerated sphenoid sinus; there are pneumatization infront and behind of the line $\mathbf{2 b}$; pneumatization can be seen in the front of the line but there is no pneumatization in the posterior, compatible with hypoplasia of the sphenoid sinus $2 \mathrm{c}$; there is no pneumatization both in front and behind the line, it is compatible with sphenoid sinus aplasia.
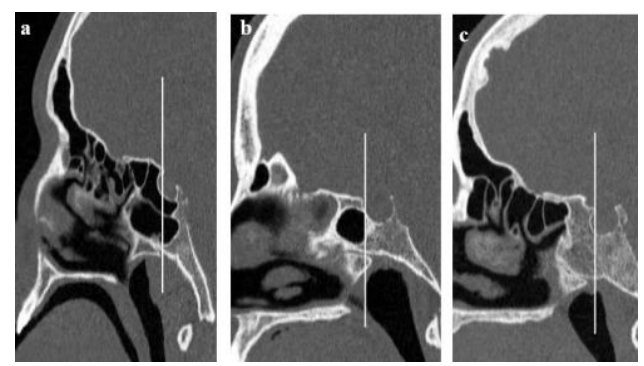

Fig. 3: Localization of the arrested pneumotization 3a;right pterygoid (arrow) $3 \boldsymbol{b}$;left pterygoid (arrow) $3 c$; basisphenoid (arrow) 
The CT images were examined independently by two radiologists experienced in head and neck radiology. Differences were discussed in a consensus meeting and a joint decision was made.

\section{Statistics}

The data were analyzed using SPSS software (ver. 26.0; IBM Corp., Armonk, NY, USA). Pearson chi-squared test was used to evaluate the relationship between sphenoid sinus hypoplasia and presence of arrested pneumatization. One way ANOVA test was used to compare the quantitative data between two groups. Duncans test was used for Post Hoc analysis. Data are expressed as numbers (n), medians, ranges, or percentages. P-values $<0.05$ were considered to indicate statistical significance. Inter-rater reliability was assessed using the kappa coefficient ( $\kappa$ ) for qualitative variables and Intraclass coefficient (ICC) for quantitative variables. An ICC and a $\kappa$ with $\leq 0$ was defined as no agreement, $0.01-0.20$ as none to slight, $0.21-0.40$ as fair, $0.41-0.60$ as moderate, $0.61-0.80$ as substantial, and $0.81-1.00$ as almost perfect agreement.

\section{Results}

Among the $841 \mathrm{CT}$ exams (386 (45.9\%) female, $455 \quad(54.1 \%$ male), 62 arrested pneumatization (27 female, 35 male) in sphenoid bone were detected (age range 1681 , mean age $39.5 \pm 16$ ). Thirty-four lesions were located in the basisphenoid region, 28 of them were located in the pterygoid bone (14 right and 14 left ) (Fig. 2). Axial and anteriorposterior dimensions were measured for all lesions; 40 of them were ${ }^{-} 1 \mathrm{~cm}$ while 22 of them were $\geq 1 \mathrm{~cm}$ (Table 2).

Table 2. Gender, age distribution and presence of sphenoid sinus hypoplasia

\begin{tabular}{lccc}
\hline & $\begin{array}{c}\text { Arrested pneumatization } \\
\text { positive } \\
(\mathbf{n = 6 2 , . 4 \% )}\end{array}$ & $\begin{array}{c}\text { Arrested pneumatization } \\
\text { negative } \\
(\mathbf{n}=\mathbf{7 7 9 , 9 2 . 5 \% )}\end{array}$ & $\begin{array}{c}\text { Total number of CTs } \\
(\mathbf{n}=\mathbf{8 4 1})\end{array}$ \\
\hline Age (Mean,SD) & $39.5 \pm 16$ & $42.6 \pm 18.6$ & $42.4 \pm 18.5$ \\
Gender (F/M, \%) & $27 / 35$ & $360 / 419$ & $386 / 455$ \\
& $43.5 \% / 56.4 \%$ & $46.2 \% / 53.7 \%$ & $45.9 \% / 54.1 \%$ \\
Sphenoid & 6 & 2 & 8 \\
hypoplasia (number,\%) & $9.6 \%$ & $0.25 \%$ & $0.9 \%$ \\
& & & \\
\hline
\end{tabular}

There was almost perfect agreement between two observers for the evaluation of presence of the arrested pneumatization $(\kappa=0.846)$ and sphenoid sinus hypoplasia $(\kappa=0.896)$. Also, a perfect agreement was found between observers for dimensions of lesions (ICC; $0.87)$.

Sphenoid sinus hypoplasia was detected in 6 patients with arrested pneumatization (9.6\%) and in only two individuals without arrested pneumatization $(0.25 \%) \quad$ (Fig. 3). One individual without arrested pneumatization had both sphenoid and maxillary sinus hypoplasia. Statistical analyses using Pearson Chi-Square test revealed that sphenoid sinus hypoplasia was significantly more common among patients with arrested pneumatization $(\mathrm{p}=0.0001)$ (Table 2).

In the Pearson Chi-Square test, there was no difference for gender between two groups ( $p=$ 0.693). ANOVA test revealed no significant difference between the groups with and without pneumatization in terms of age $(\mathrm{p}=$ $0.214)$.

In the Posthoc analysis performed with Duncan test, it was determined that there was a statistically more probability of hypoplasia, especially in lesions larger than $1 \mathrm{~cm}$ in size $(\mathrm{p}$ $=0.001)$. Lesions smaller than $1 \mathrm{~cm}$ did not have a statistically significant relationship with the presence of hypoplasia $(p=0.1)$ 
(Table 3). Also, it was determined that the possibility of hypoplasia was statistically less in patients with lesions located in the right pterygoid $(\mathrm{p}=0.001)$. However, there was no difference between the left pterygoid location and the basisphenoid location in terms of the presence of hypoplasia $(\mathrm{p}=0.07)$ (Table 3 ).

Table 3. Evaluation of the relationship between the presence of sphenoid sinus hypoplasia and the location and size of the lesion in patients with arrested pneumatization

\begin{tabular}{|c|c|c|c|c|}
\hline & $\begin{array}{l}\text { Sphenoid sinus } \\
\text { hypoplasia } \\
(\mathrm{n}=6)\end{array}$ & $\begin{array}{c}\text { Normal aerated sphenoid } \\
\text { sinus } \\
(\mathrm{n}=56)\end{array}$ & $\begin{array}{c}\text { Total number of arrested } \\
\text { pneumotization positive } \\
\text { patients } \\
(\mathrm{n}=62)\end{array}$ & $\mathbf{p}$ \\
\hline Basiphenoid (n,\%) & $5(83.3 \%)$ & $29(51.7 \%)$ & $34(54.8 \%)$ & 0.14 \\
\hline Right pterygoid (n,\%) & $0(0 \%)$ & $14(25 \%)$ & $14(22.5 \%)$ & $0.001 *$ \\
\hline Left pterygoid (n,\%) & $1(16.6 \%)$ & $13(23.2 \%)$ & $14(22.5 \%)$ & 0.07 \\
\hline$<1 \mathrm{~cm}(\mathrm{n}, \%)$ & $4(6.6 \%)$ & $36(64.2 \%)$ & $40(64.5 \%)$ & 0.1 \\
\hline$\geq 1 \mathrm{~cm}(\mathrm{n}, \%)$ & $2(3.3 \%)$ & $20(35.7 \%)$ & $22(35.4 \%)$ & $0.001 *$ \\
\hline
\end{tabular}

Post Hoc analysis with Duncan test. ${ }^{*}$ statistically significant

\section{Discussion}

This study evaluated the prevalence of arrested pneumatization in a screened population and determined the relation with sphenoid sinus aeration in a cross-sectional study design. The prevalence of arrested pneumatization was $7.4 \%$ in our study population. There was a significant correlation between the arrested pneumatization and sphenoid sinus hypoplasia. To the best of our knowledge, this is the first study that evaluates the correlation of sphenoid sinus hypoplasia and the presence of arrested pneumatization in English-speaking literature.

Although arrested pneumatization can be observed in all bones that develop aerated cavities following fat involution, it is much more defined for sphenoid bone (5). This mechanism was shown also for frontal sinus $(1,10)$ and maxillary sinus $(8)$. The signal intensity changes (SI) of bone marrow in MRI enabled us to understand the mechanism of the aeration process of paranasal sinuses. In a retrospective MRI study, Szolar et al. investigated the bone marrow changes under the age of 15. They reported that; at the age of four months the SI was similar to that of red bone marrow then SI gradually changed from hypointense to hyperintense by the age. This signal intensity changes support the fatty involution of bone marrow precedes the appearance of aeration. At the beginning, sphenoid sinus is small, and fat involution is still present in the periphery. Thus, pneumatization of the sphenoid bone appears to occur after occupation of bone marrow cavity with fatty bone marrow. Arrested pneumatization of the skull base is considered to be the non-aerated areas of bone marrow involution (11).

In a recent MRI study, analyzed the prevalence of arrested pneumatization in children with hematologic disorders, authors reported that patients with hematologic diseases like sickle cell anemia and thalassemia involving red-blood-cells had a higher prevalence of arrested pneumatization of the sphenoid sinus and the authors attributed these results to regional blood-flow changes (8). Also, Prabhu et al. investigated the CT prevalence of arrested pneumatization in patients with sickle cell anemia. Authors had reported the prevalence of arrested pneumatization in patients with sickle cell anemia around $9.6 \%$, while the range was $2.1 \%$ in the control group. Although these results support the regional blood flow differences as a potential cause of arrested sinus, it has not been proven yet. In addition, it is unclear whether increased serum erythropoietin levels in sickle cell anemia patients have a potential role in this condition (2). Moreover, some authors had defended a possible reactive response to temperature and circulatory changes during the pneumatization 
period as to be a reason for the development of arrested pneumatization (5). We found the prevalence of arrested pneumatization in a screened population as $7.4 \%$ with an unknown history of hematologic disorders.

Kuntzler et al. examined not only sphenoid sinus but also maxillary, frontal and ethmoidal sinuses for arrested pneumatization by CT imaging. Authors reported that the maxillary and frontal sinuses were also possible localizations for arrested pneumatization as well as the sphenoid sinus. They did not detect arrested pneumatization at the location of the ethmoid sinus and attributed this to the fact that the ethmoid sinuses were present at birth and development was different from other paranasal sinuses (10). In the current study, we did not evaluate the arrested pneumatization in the maxillary, frontal and ethmoid sinuses, while we found arrested pneumatization in 62 of sphenoid sinuses which most of the lesions were located in the basisphenoid (34/62). As distinct from previous studies, we also evaluated the correlation of sphenoid sinus hypoplasia with arrested pneumatization. With the comparison of patients without arrested pneumatization, the hypoplasia of the sphenoid sinus was seen significantly more in the patients (6/62) with arrested pneumatization.

Absence and hypoplasia of sphenoid sinuses are rare in adults. In a dental volumetric CT study, authors reported the prevalence of a percentage for sphenoid sinus hypoplasia $0.52 \%$ in 384 CT images (9). We used a similar technique in determining the hypoplasia or aplasia of the sphenoid sinus with the authors. We found $0.25 \%$ sphenoid sinus hypoplasia in patients without arrested pneumatization and the percentage was 9.6 in patients with arrested pneumatization. Similar to the previous study the prevalence of sphenoid sinus hypoplasia was found to be around $0.9 \%$ for the whole population in our series.

Benign lesions such as osseous lipoma and hemangioma, and local aggressive tumors such as fibrous dysplasia and chordoma, as well as more aggressive tumors such as chondrosarcoma, may be confused with arrested pneumatization by causing similar radiological findings $(2,12)$. Although accustomed to pneumatization variations, recognition of arrested pneumatization is very important in order to avoid unnecessary investigations and interventional procedures by radiologists. MRI findings of arrested pneumatization may be more confusing than CT findings. Therefore, its described as a 'pseudo lesion' and CT confirmation and follow-up should be performed to prevent misdiagnosis of osseous tumoral lesions (Fig. 4). Cone beam CT and MRI findings of two cases were described by Tahmasbi-Arashlow et al.; authors suggested that sometimes not all of the diagnostic features defined for arrested pneumatization may be found and the recommended follow-up of the lesions to avoid unnecessary intervention in such cases (4).

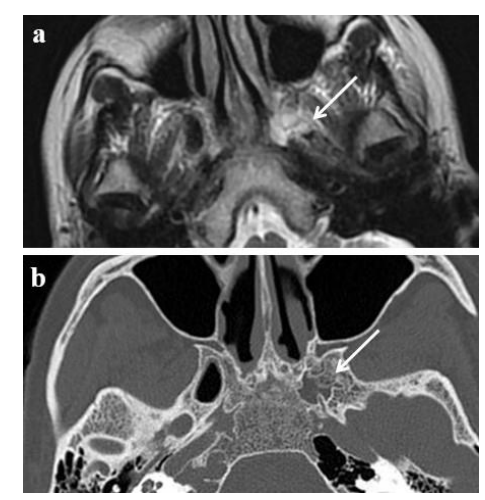

Fig.4a; In the T2 weighted axial MR image, there is an asymmetrical hyperintensity on the left pterygoid process $\boldsymbol{b}$; on CT examination, it is seen that this belongs to an obvious arrested pneumatization with a sclerotic rim around it in the left pterygoid bone (arrow). 
Despite the fact that the retrospective design seems to be the main limitation of the study, including a large number of images increase the strength of the analyses. As this was a cross-sectional anatomical study, it was impossible to relate the results with suggested potential clinical aetiologies.

\section{REFERENCES}

1. Scuderi AJ, Harnsberger HR, Boyer RS. Pneumatization of the paranasal sinuses:normal features of importance to the accurate interpretation of CT scans and MR images. $A J R$ Am J Roentgenol 1993;160:1101-4.

2. Prabhu AV, Branstetter BF 4th. The CT Prevalence of Arrested Pneumatization of the Sphenoid Sinus in Patients with Sickle Cell Disease. Am J Neuroradiol. 2016;37:1916-1919.

3. Welker KM, DeLone DR, Lane JI, Gilbertson JR. Arrested pneumatization of the skull base: imaging characteristics. Am J Roentgenol. 2008 ;190:1691-6.

4. Tahmasbi-Arashlow M, Barghan S, Bennett J, Katkar RA, Nair MK. Arrested Pneumatization of the Sphenoid Sinus on Large Field-of-View Cone Beam Computed Tomography Studies. Dent J (Basel). 2015; 11;3:67-76.

5. Aoki S, Dillon WP, Barkovich AJ, Norman D. Marrow conversion pneumatization of the sphenoid sinus: assessment with MR imaging. Radiology 1989;172:373-5.

6. Gurevitch O, Slavin S, Feldman AG. Conversion of red bone marrow into yellow - Cause and mechanisms. Med Hypotheses 2007;69:531-6.

7. Yonetsu K, Watanabe M, Nakamura T. Agerelated expansion and reduction in aeration of the sphenoid sinus: volume assessment by helical CT scanning. Am J Neuroradiol.2000;21:179-82.

8. Arpaci T. Arrested pneumatization of the sphenoid sinus mimicking skull base tumours: MRI prevalence in children with haematologic diseases. Int J Neurosci. 2018 ;128:1040-43.

9. Cakur B, Sümbüllü MA, Yılmaz AB. A retrospective analysis of sphenoid sinus hypoplasia and agenesis using dental volumetric $\mathrm{CT}$ in Turkish individuals. Diagn Interv Radiol. 2011;17:205-8.

10. Kuntzler S, Jankowski R. Arrested pneumatization: witness of paranasal sinuses development? Eur Ann Otorhinolaryngol Head Neck Dis. 2014;131:167-70.

11. Szolar D, Preidler K, Ranner G, Braun H, Kern R, Wolf G, Stammberger H, Ebner F. Magnetic resonance assessment of age-related development of the sphenoid sinus. Br J Radiol. 1994;67:431-5.

\section{Conclusion}

This study showed that arrested pneumatization has a relation with sphenoid sinus aeration. This situation may be due to the ongoing development process of aeration of the sphenoid sinus with the fatty conversion of the sphenoid bone

12. Jalali E, Tadinada A. Arrested pneumatization of the sphenoid sinus mimicking intraosseous lesions of the skull base. Imaging Sci Dent. 2015;45:6772. 